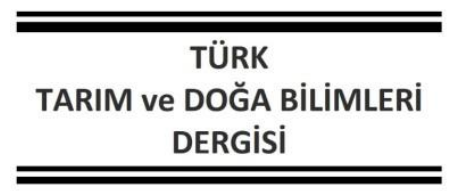

\title{
Araştırma Makalesi \\ Demographic factors affecting Regular Bottled Water Consumption: Adana Province/Turkey
}

www.dergipark.gov.tr/turkjans

\author{
Arzu SEÇER ${ }^{1}$, Mutlu BULUT ${ }^{2 *}$ \\ ${ }^{1}$ Çukurova Üniversitesi, Ziraat Fakültesi, Tarım Ekonomisi Bölümü, Adana \\ ${ }^{2}$ Meteoroloji Genel Müdürlüğü, Şakirpaşa Havaalanı Meteoroloji Müdürlüğü, Adana \\ *Sorumlu Yazar: mtlbulut@gmail.com \\ Received: 08.07.2020, Revised in received: 05.01.2021, Accepted: 10.01.2021
}

\begin{abstract}
In Turkey, bottled water market has shown a rapid development since the 1990s. This study is aim to reveal demographic and economic factors affecting on bottled water consumption in Adana. A logistic regression model was used to achieve research goal. The results of the study showed that women consumers, with undergraduate and higher education consumers and individuals with monthly income of $2500 \mathrm{TL}$ are more likely to consume bottled water. However, there is no relationship between age, marital status and household size variables and bottled water consumption. Bottled water companies should take into account to gender, education level and income level in their marketing strategies.
\end{abstract}

Keywords: Bottled water, logit analysis, Demographic factors, Adana

\section{Adana'da Ambalajlı Su Tüketimini Etkileyen Demografik ve Ekonomik Faktörler}

\section{Öz}

Türkiye'de ambalajı su sektörü 1990'lardan bu yana hızlı bir gelişme göstermiştir. Bu çalışma Adana'da ambalajlı su tüketimini etkileyen demografik ve ekonomik faktörleri ortaya koymak amacıyla yürütülmüştür. Araştırma sonuçlarına göre üniversite ve daha yüksek seviyede eğitime sahip bireyler, kadınlar ve aylık geliri 2500 TL üzerinde olan bireylerin ambalajı su tüketme olasılıkları daha yüksektir. Ancak yaş, medeni durum ve hane halkı büyüklüğü ile ambalajlı su tüketimi arasında bir ilişki yoktur. Ambalajlı su şirketleri, pazarlama stratejilerinde cinsiyet, eğitim düzeyi ve gelir düzeyini dikkate almalıdır.

\section{Anahtar kelimeler: Ambalajlı su, logit analizi, demografik faktörler, Adana}

\section{Introduction}

Bottled water stands for one of the fastest developing drinks market in the world. Recent predicting show that it is likely to overreach soft drinks and become the largest beverage category by volume in the last 30 years. Today, even in developed countries where tap water is very reliable and inexpensive, bottled water consumption has rapidly increased. This increase enquires concerning why consumers with flawlessly good tap water, that costs far fewer, choose a more expensive and environmentally harmful alternative like bottled water (Rodwan, 2016).

The amount of bottled water consumption has increased between 2007 and 2017 in the world. The annual bottled water consumption was 391 billion liters, an increase about \%54 compared to 2007 (Statista, 2020). USA is one of the most important countries where amount of bottled water consumption has increased. According to the recent data, bottled water consumption in the USA increased by $59 \%$ compared to 2006, reaching 52.4 billion in 2018 (Bedford, 2020). The countries with the highest consumption of bottled water per capita are Italy (188.5 L), Germany (177.3 L) and France (139.3 L) (Rodwan, 2016). While bottled water consumption per capita was 96 liters in 2007 (KUDAKA, 2012), it was 149 liters in 2017 in Turkey (SUDER, 2019).

In Turkey, bottled water market has shown a rapid development since the 1990s. In these years, a serious drinking water problem has occurred especially in important cities, which have high population such as Istanbul, Ankara and Izmir. The consumers have experienced the problems related to the inadequate taste, purity, color and odor of the tap water and this issue has affected to the bottled water consumption remarkably. These 
problems led to the emergence of bottled water companies and they present bottled water both previous retail units (markets, supermarkets, restaurants, etc.) and their own water stations to sell clean and reliable drinking water to people. In 2008 , Turkey bottled water industry has a volume of 8,7 billion liters consumption and 3,4 billion TL with annual turnover (KUDAKA, 2012). When 2018 statistics examined, Turkey bottled water industry has a volume of 12.1 billion liters consumption and 7,1 billion TL with an annual turnover (SUDER, 2019).As It can be seen, the bottled water market volume increased by \%39.1 and annual turnover increased by $108 \%$ during2008-2018 period. According to these statistics, it can be said that the bottled water market has grown significantly both in volume and in annual turnover.

The improvement of the bottled water market has attracted the attention of not only companies but also researchers. Many studies have been conducted on bottled water and drinking water consumption in Turkey and worldwide. FifeShaw et al. (2007) stated that consumers with lower education than university degrees have higher satisfaction levels with tap water provided by the municipality. Similar results have been presented for lower income and younger consumers. Hobson et al. (2007) carried out a research on people's drinking water consumption preferences based on ethnicity in Utah, USA. In this study, it was determined that $30 \%$ of married couples never drink tap water and $42 \%$ of them never drink tap water in the residential area, the majority of which consists of (80\%) Spanish citizens. All of the Spanish individuals who consume since they think that tap water is not enough quality for their health. Dupont et al (2010) evaluated the differences in water consumption preferences in terms of sociodemographic factors in Canada. In the study, multinominal logit model was used to examine water consumption preferences in a multivariable framework. According to Dupont et al, factors increasing higher possibilities of a participant being a bottled water consumer (relation to the preference of tap water) include higher income, bad taste experience with tap water. Ghebregiorgis and Mehreteab (2018) carry out a study to determine the relationship between bottled water purchasing behavior and demographic and psychological factors in Eritrea. They state that no relationship was determined socio-demographic variables affecting consumers' bottled water drinking behaviour. The results show that as consumers' perception increases, they believe that tap water is healthier and more reliable than bottled water in Eritrea. Etale et al (2018) compared the bottled water and tap water consumption habits of the
German and Swiss consumers in terms of social norms and images. According to research results, most of Swiss consumers use tap water, while most of German consumers prefer bottled water. Gender of consumers is statistically important factor in drinking water consumption whereas; age and education level had no significant effect on consumption preferences in Switzerland. Geerts et al (2020) determined the drinking water consumption preferences of consumers in Belgium. Consumers stated that water is more reliable and it has good taste comparing to tap water. On the other hand, it was found out that the consumption of bottled water was more common among men and older consumers.

The aim of this study is to investigate demographic (gender, age, education, household size) and economic (monthly family income and working status) factors affecting on bottled water consumption in Adana, Turkey.

\section{Material and Method}

The main material of the study consisted of primary data, which were obtained from face to face questionnaire with consumers in Adana province. In order to prepare the questionnaire used in the study, previous studies were examined and were asked to experts in the field (Bal, 2014; Foote, 2011; Janmaat, 2007; Jones et al., 2006; Talatala, 2008; ikikat Tümer et al., 2011). The questionnaire was pretested on a set of 20 participants to assess its validity and reliability. Then, the final version of the questionnaire was compiled.

The survey carried out among households of the central Adana. Adana is situated in the south and in the sixth largest province in Turkey. The population of the study is consisted of consumers in the center of Adana. Sample size was determined by "One Stage Simple Random Sampling" method. This method is used commonly in consumer studies. Formula of the method is given at the below (Malhotra 2004; Hair and ark., 2000).

$$
n=z^{2} \frac{(p \times q)}{d^{2}}
$$

$\mathrm{n}$ : Sample size

z: 1,96 ( $z$ value for confidence interval of 95\%)

$q:(1-p)$ The ratio of the main population without the relevant feature.

$\mathrm{d}$ : Accepted error level. Is is accepted as $5 \%$.

$\mathrm{p}$ : the ratio of the main population with a specific feature based on preliminary information or prediction on the subject under consideration (0.5).

The sample size is calculated as 384 persons with $95 \%$ confidence interval and 5\% error level. 


\section{Method to reveal factors effecting bottle water consumption}

A binary logistic regression model was adopted to determine the extent to which selected demographic and economic characteristics. Binary logistic regression is also called a logit model. This model is usually used when the dependent variable is dichotomous and the independent variables are either continuous or categorical variables. Specifically, it is employed To model the relationship between the categorical dependent

variable and one or more independent variables by estimating probabilities using a logistic function. Normally, the outcome in logistic regression analysis is coded as 0 or 1 , where 1 indicates that the outcome of interest is present, and 0 indicates that the outcome of interest is ignored (Hair et al. 2006).

\section{Model Specification}

The logistic regression function has two common representations, as follows (Ge and Withmore, 2007).

$$
\begin{gathered}
\begin{array}{c}
p=\mathrm{E}(y \mid \boldsymbol{X} \boldsymbol{\beta})=[1+\exp (-\boldsymbol{X} \boldsymbol{\beta})]^{-1} \\
\ln \left(\frac{p}{1-p}\right)=\boldsymbol{X} \boldsymbol{\beta}
\end{array}
\end{gathered}
$$

The first representation (1) shows the logistic form of the relationship between probability $p$ and the linear combination $\boldsymbol{X} \boldsymbol{\beta}$. The second form (2) re-expresses the probability using a logit transformation, which amounts to taking the logarithm of the odds of event $H$ happening. The logit transformation is sometimes referred to as the log-odds.

In this research, demographic and economic factors effecting on bottled water consumption preferences was examined. A logistic regression model was used to determine the factors that affected using regular bottled water consumption. Dependent variable is defined as consumers' bottled water consumption preferences. Consumers interviewed in the research divided into two categories as "regular bottled water consumers" and "irregular bottled water consumers". Regular bottled water consumers are defined as "the consumer who buys bottled water regularly in houses, workplaces or both of them". The other category (irregular bottled water consumers) represents "the consumers use generally tap water and prefer bottled water under some circumstances".

The dependent variables used in the model were coded as regular bottled water consumers (1) and irregular bottled water consumers (0). The explanatory variables selected from the demographic and economic characteristics of the consumers were transformed into dummy variables as described in Table 1.

\begin{tabular}{|c|c|c|}
\hline Variable Name & Mean/\% & Std. Dev. \\
\hline \multicolumn{3}{|l|}{ Bottled water consumption } \\
\hline Regular bottled water consumption $=1$ & 59,6 & - \\
\hline Otherwise $=0$ & & - \\
\hline \multicolumn{3}{|l|}{ Age (mean:53,38 years) } \\
\hline Between 18 and $45=1$ & 30,5 & 5,60 \\
\hline \multicolumn{3}{|l|}{ Otherwise $=0$} \\
\hline \multicolumn{3}{|l|}{ Gender } \\
\hline Male $=1$ & 46,9 & \\
\hline \multicolumn{3}{|l|}{ Otherwise $=0$} \\
\hline \multicolumn{3}{|l|}{ Education } \\
\hline Undergraduate level or above=1 & 18,2 & \\
\hline \multicolumn{3}{|l|}{ Otherwise $=0$} \\
\hline \multicolumn{3}{|l|}{ Household size } \\
\hline $4<=1$ & 67,5 & \\
\hline \multicolumn{3}{|l|}{ Otherwise $=0$} \\
\hline \multicolumn{3}{|l|}{ Marital status } \\
\hline Married=1 & 67,7 & \\
\hline \multicolumn{3}{|l|}{ Otherwise $=0$} \\
\hline \multicolumn{3}{|l|}{ Occupation } \\
\hline Working=1 & 69,79 & \\
\hline \multicolumn{3}{|l|}{ Otherwise $=0$} \\
\hline \multicolumn{3}{|l|}{ Income (mean: $2.739 \mathrm{TL}$ ) } \\
\hline $2500>=1$ & $\% 51,6$ & 1557.03 \\
\hline Otherwise $=0$ & & \\
\hline
\end{tabular}

Table 1. Descriptive Statistics for the explanatory variables entered in the model 


\section{Results}

Many factors affect the purchasing decisions of consumers. These are influenced by the most intrinsically expressed factors such as the personality, self, sensation and perception of consumers, memory and learning capacity, as well as various external environment elements. The demographic features of the consumers come first among these elements. In order to evaluate consumers objectively, it is necessary to examine how people consume according to some demographic features. Demographic features are their inherent physical, social, economic and geographical attitudes that determine the individual and explain his place in the social environment (Wells and Prensky, 1996: 131).

The model was statistically significant $\left(X^{2}\right.$ $(d f=6, n=384)=19,144, P<0,05)$. The 2Log likelihood value of the model was 498,843 , the Cox and Snell R2 was 0,049 , and the Nagelkerke $R^{2}$ value was 0,066 According to the classification table, $27,7 \%$ of adopters, $87,3 \%$ of non-adopters, and $63,3 \%$ of all subjects were correctly classified. The logistic regression results are presented in Table 2.

Of the 6 variables entered in the model, 3 were statistically significant, and they had expected signs. The significant variables were gender, education and monthly family income. According to the results of logistic analysis, these are the factors influencing regular bottled water consumption.

The $\operatorname{Exp}(B)$ values for the significant variables are interpreted as follows

1. Provided that all other explanatory variables remain constant, a one unit increase in gender decreases the probability of being regular bottled water consumers 0,531 times. This means that women are 0,531 times more likely to be regular bottled water consumers than men.

2. Holding all other explanatory variables constant, a one unit increase in education increase the probability of buying bottled water regularly by 1,639 times. This implies that a consumer who had education undergraduate and above had 1,639 times higher probability of being regular bottled water consumer.

3. Similarly the $\operatorname{Exp}(B)$ values were 1,641 for income level. It means that a consumer who had income higher than $2500 \mathrm{TL}$ and above had 1,641 times higher probability of being regular bottled water consumer.

4. However, there is no relationship between regular bottled water consumption and marital status, age and household size. In the other words, marital status, age and household size had no effect on regular bottled water consumption.

Table 2. Factors influencing regular bottled water consumption: The logistic regression analysis

\begin{tabular}{lccccc}
\hline Factors & B & S.E. & Wald & Sig. & Exp(B) \\
\hline Gender & $-0,633$ & 0,217 & 8,495 & 0,004 & 0,531 \\
Marital Status & 0,097 & 0,248 & 0,152 & 0,696 & 1,102 \\
Age & 0,104 & 0,251 & 0,173 & 0,677 & 1,110 \\
Education & 0,494 & 0,239 & 4,259 & 0,039 & 1,639 \\
Household Size & 0,040 & 0,233 & 0,030 & 0,863 & 1,041 \\
Income & 0,495 & 0,218 & 5,142 & 0,023 & 1,641 \\
Constant & $-0,807$ & 0,307 & 6,891 & 0,009 & 0,446 \\
\hline
\end{tabular}

$B$, coefficients; SE, standard error; $\chi 2$, chisquare; $d f$, degrees of freedom; $P$, significance level; $\operatorname{Exp}(B)$, odds values. $\mathrm{P}<0.05$ is considered statistically significant.

\section{Conclusion}

Water is very important for human life and, today it is a commercial product that can be easily bought and sold in many forms and packing materials. In this study, the aim is toreveal the demographic factors affecting regular bottled water consumption in the Adana province.

As a result of the research, 3 of the 6 demographic variables analyzed have found statistically significant. Demographic variables affecting packaged water consumption have determined as gender, education and monthly family income.

The results of the study showed that women consumers are more likely to consume bottled water than men consumers. Similarly, consumers with undergraduate and higher education are more likely to consume bottled water. When the effect of monthly income of families on the consumption of bottled water was examined, it was determined that individuals with monthly income of $2500 \mathrm{TL}$ and above were more likely to consume packaged water. It has been determined that the marital status, age and family sizes of consumers have no effect on bottled water consumption. The results indicate that bottled water companies should aim to target the demands of women, highly educated 
and those with high income in their marketing strategies. At present, efforts to ensure product demand and brand loyalty are essential for nonregular consumers.

In today's intense competitive conditions, companies should be able to understand consumer behavior accurately and on time in order to increase the prefer ability of their products. In addition, living conditions have changed, and accordingly, the consumption patterns of consumers have also changed. This research is an important study in terms of guiding the companies operating in the bottled water sector to form their marketing strategies. Business industry want to know the factors that affect consumers' purchase of certain goods and services. So, the findings of this study will contribute to the determination of the future sales strategies of bottled water companies. If bottled water companies have sufficient information about the consumption structure of individuals, they can make better plans and thus increase their profitability.

\section{References}

Alexandria, V. A. 2018. Consumers reaffirm bottled water is America's favorite drink. Erişim:https://www.bottledwater.org/consu mers-reaffirm-bottled-water-america \%E2\%80\%99s-favorite-drink (16.02.2020)

Aliaga, M. Gunderson, B. 2002. Interactive statistics. [Thousand Oaks]: Sage Publications

Bal Ekmekçi Z. 2014. Tokat il Merkezinde Tüketicilerin Ambalajlı Su Tüketimleri Üzerine Bir Araştırma. Gaziosmanpaşa Üniversitesi Fen Bilimleri Enstitüsü, Yüksek Lisans Tezi, Tokat, $58 \mathrm{p}$.

Bedford, E. 2020. Volume of Bottled Water in the U.S.

Doria MF. 2006. Bottled water versus tap water: understanding consumers' preferences. J. Water Health 4 (2) 271-276.

Doria, M. F., Pidgeon, N., Hunter, P. R. 2009. Perceptions of drinking water quality and risk and its effect on behavior: A crossnational study. Sci Total Environ 407, 54555464 (2009).

Dupont, D. P., Adamowicz, W., Krupnick, A. 2010. Differences in water consumption choices in Canada: the role of socio-demographics, experiences and perceptions of risks. J Water Health 8:671-686

Etale, A., Jobin, M., Siegrist, M. 2018. Tap versus bottled water consumption: The influence of social norms, affect and image on consumer choice. Appetite, 121, 138- 146.

Ferrier C. 2001. Bottled Water: Understanding a Social Phenomenon. AMBIO: A Journal of the
Human Environment. https://doi.org/ 10.1579/0044-7447-30.2.118

Fife-Shaw, C., Kelay, T., Vloerbergh, I., Chenoweth, J., Morrison, G., Lundéhn, C. 2007. Consumer Preferences: An Overview. Techneau. http://www.techneau.org/

fileadmin/files/Publications/Publications/De liverables/D6.2.1.pdf, (Access Date: Mar 31 2011).

Foote, M. L. 2011. Examining reasons for bottled water consumption: A case study in pensacola. MSc Thesis. Florida University of South Florida.

Withmore, G. 2007. Binary response and logistic regression in recent accounting research publications: a methodological note. Lecture note. McGill University, Desautels Faculty of Management

Geerts, R., Vandermoere, F., Van Winckel, T., Halet, D., Joos, P., Van Den Steen, K., Van Meenen, E., Blust, R., Borregán-Ochando, E., Vlaeminck, S. E. 2020. Bottle or tap? To-ward an integrated approach to water type consumption. Water Res. 173, 115578.

Hair, J. F., Black, W. C., Babin, B. J., Anderson, R. E., Tatham, R. L. 2006. Multivariate Data Analysis. New Jersey: Pearson Prentice Hall.

Hobson, W., Knochel, M., Byington, C., Young, P., Hoff, C., and Buchi, K. 2007. Bottled, filtered, and tap water use in latino and non-latino children. Archives of Pediatrics and Adolescent Medicine, 161(5): 457-461.

İkikat Tümer E, Birinci A, Yildirim Ç. 2011. Ambalajlı su tüketimini etkileyen faktörlerin belirlenmesi: Ankara ìli Keçiören İlçesi Örneği. Alınteri Zirai Bilimler Dergisi, 21(2), 11-19.

Janmaat, J. 2007. Divergent drinking water perceptions in the annapolis valley. Canadian Water Resources Association. Vol. 32(2):99110.

Jones, A. Q., Dewey, C. E., Dore, K., Majowicz, S. E., MCeven, S. A., Waltner-Toews, D. 2006. Drinking water consumption patterns of residents in a Canadian community. Journal of Water and Health. IWA Publishing.

Jonstone, N., Serret, Y. 2012. Determinants of bottled and purified water consumption: results based on an OECD survey. Water Policy (2012) $14 \quad$ (4): 668-679. https://doi.org/10.2166/wp.2011.048

Kudaka, 2012. Ambalajlı İçme Suyu Sektörü. http://www.kudaka.org.tr/ekler/5dc8bambalajli_icme_suyu_projesi.pdf (AccesDate: 16.05.2020).

Miller, M. 2006. Bottled water: Why is it so big? causes for the rapid growth of bottled water 
industries. University Honors Program. URL: https://digital.library.txstate.edu/bitstream /handle /10877/3296/fulltext.pdf (Accesed 21 February 2020).

Ross, V. L., Fielding, K. S., Louis, W. R. 2014. Social trust, risk perceptions and public acceptance of recycled water: Testing a socialpsychological model. Journal of Environmental Management, 137, 61-68.

Saylor, A., Prokopy, L. S., Amberg, S. 2011. What's wrong with the Tap? Examining Perceptions of Tap Water and BottledWater at Purdue University. Environ. Manag. 2011, 48, 588601.

Statista Research Department, 2020. Global Water Consumption 2007-2017. Erişim: https://www.statista.com/statistics/387255 /global-bottled-water-consumption/ (16.02.2020)

SUDER, 2019. Genel yapı ve rakamsal büyüklük. Erişim:http://suder.org.tr/sektorhakkinda/genel-yapi-ve-rakamsal-buyukluk/ (17.02.2020)

Talatala, S. 2008. The effect of tap water perception on the consumption of bottled water. Published in: Public perception of tap water. URL:

https://nature.berkeley.edu/classes/es196/ projects/2008final/Talatala_2008.pdf (Accesed 11 May 2017).

Wells, W. D., Prensky, D. 1996. Consumer Behavior. Kanada: John Wiley \& Sons, Inc

Yoo, S., Yang, C. 2000. Dealing with bottled water expenditures data with zero observations: $A$ semiparametric specification. Economics Letters, Volume 66, Issue 2, Pages 151-157. 